\title{
Characterization of Austenite Decomposition in Steels with Different Chemical Concepts and High Potential to Manufacture Seamed Pipes for Oil and Gas Industry
}

\author{
Rogério Antão Cardoso ${ }^{a}$, Geraldo Lúcio de Faria ${ }^{*}$ *(D) \\ ${ }^{a}$ Universidade Federal de Ouro Preto, Ouro Preto, MG, Brasil
}

Received: June 12, 2019; Revised: August 07, 2019; Accepted: August 25, 2019

\begin{abstract}
This work presents the characterization of austenite decomposition kinetics in two steels during continuous cooling considering non-deformed austenite grains. Two different chemical concepts of steels were evaluated: low carbon - high manganese and a relatively new concept based on low carbon - low manganese - high niobium contents. Dilatometric experiments, microstructural characterization procedures and microhardness tests were carried out. Experimental and calculated CCT diagrams were plotted and the adapted JMAK model was applied aiming to predict the austenite decomposition kinetics. The low carbon - high manganese steel was the most sensitive to the applied cooling rates and, due to that, presented the higher grain refinement and hardness increasing after continuous cooling. These results highlight that the Mn content decreasing may promote a potential loss of grain refinement in procedures of continuous cooling where the structure recrystallization does not occur, as in some welding procedures or conventional heat treatments applied in the seamed pipe manufacturing process.
\end{abstract}

Keywords: $\mathrm{Nb}$ and $\mathrm{Mn}$ contents, austenite decomposition, continuous cooling.

\section{Introduction}

In order to meet the requirements for oil and gas industry, a usually processing route for development of line pipe steels is the Thermomechanical Controlled Process (TMCP) of low-carbon microalloyed steels. The TMCP consists of a controlled hot rolling followed by an accelerated cooling process. This route is commonly used to maximize the benefits of microalloying elements on the steel grain refinement ${ }^{1-5}$.

Hot-rolled steel strips are welded both internally and externally during the pipe manufacturing process ${ }^{5}$. The thermal effect of the welding stage promotes changes in the microstructure and, consequently, in the mechanical properties of the base metal adjacent to the weld line. As a result of the exposure to high temperatures, the change in the microstructure may lead to local brittleness in the Heat Affected Zone (HAZ). After the cooling, the HAZ becomes a significant microstructural discontinuity of the pipe. In addition, defects, stress concentration and higher residual stresses are easy to coexist in the weld joint. If not controlled, this region may represent a critical region susceptible for effects related to local plastic strain, fatigue crack nucleation and growth, and toughness loss ${ }^{6-8}$.

Some authors have evaluated the possibility of applying post-welding heat treatments in order to decrease the microstructural gradient of the HAZ, increasing the fatigue crack nucleation strength and avoiding the local toughness loss 9-11. However, seeking to plan efficient heat treatments, it is necessary accurate knowledge about the critical temperatures and the kinetics of phase transformation in steels.
The knowledge about the influence of cooling rate on phase transformations and final microstructure is a useful tool that may be applied as a reference for accelerated cooling schedules choices during the TMCP, as well as to understand welding microstructural effects and to plan post-welding heat treatments. Many authors emphasize the importance of dilatometric tests and experimental studies of phase transformation kinetics aiming to provide information about the behavior of austenitized steels under conventional continuous cooling 3,4,12-14.

API 5L grade X65 steel is an example of steel that are manufactured using TMCP and its steel concept is based on low carbon and high manganese $(\mathrm{Mn})$ contents ${ }^{5,15}$. The Mn $(0.80-1.20 \mathrm{wt} \%)$ is used as a solid solution hardening element and, as it is an austenite stabilizer, it reduces the activity of carbon in austenite and retard the austenite decomposition. Such phenomenon can prolong the incubation time for polygonal ferrite formation, retarding the transformation kinetics, thus decreasing the transformation temperature and contributing to the steel grain refinement ${ }^{16,17}$.

However, due to the development of more aggressive corrosion tests and more stringent requirements related to steel corrosion performance, there is a tendency to decrease the Mn content on steels ( $<0.30 \mathrm{wt} . \%)$ and, consequently, to decrease the sulfur content as well $(<0.002 \mathrm{wt} . \%)$ in order to prevent the formation of $\mathrm{MnS}$ inclusions ${ }^{18,19}$. This steel chemical composition concept improves the corrosion performance, but it is necessary to compensate the decrease in Mn content applying other methods to ensure the steel mechanical strength. Thus, the content of microalloying elements can be increased and the TMCP strategy and welding procedures must be improved ${ }^{20}$. 
Niobium $(\mathrm{Nb})$ is an important microalloying element that has been studied for application on this concept of steel (low carbon - low manganese - high microalloying elements). $\mathrm{Nb}$, in solid solution, strongly affects the austenite to ferrite transformation. Because of the large lattice misfit of $\mathrm{Nb}$ atom in ferrous matrix, it segregates to austenite grain boundaries where interacts with carbon which has stronger affinity with $\mathrm{Nb}$ than $\mathrm{Fe}$. Such interaction restricts the diffusion of carbon from ferrite and there is a decreasing in the local driving force for ferrite nucleation. These effects lead to a decrease in the nucleation rate of ferrite ${ }^{21-24}$.

Seeking to contribute to the understanding about the effects of chemical composition on the austenite decomposition under continuous cooling, the present study characterized the kinetics of austenite to ferrite/ pearlite/bainite transformation, considering a specific and critical situation where the previous austenitic grains were non-deformed and a relatively low austenitizing temperature, where the $\mathrm{Nb}$ were not completely in solid solution. This is an important condition because after TCMP processing, the product microstructure can be submitted to welding procedures where, somewhere along the HAZ, the austenite grains will not be deformed and the $\mathrm{Nb}$ will not be completely solubilized. Besides that, the most part of commercial heat treatments uses a relatively low austenitizing temperature and these premises continue valid. In this context, both studied steels, presenting different chemical composition concepts, were evaluated in the same austenitizing condition.

\section{Materials and Methods}

\subsection{Materials}

The as-received materials used in this research were two low-carbon steels presenting different contents of elements. The chemical composition of these steels is given in Table 1.

Steel A fits into the class of low carbon - low manganese - high niobium, which is a relatively new concept that has been studied for development of API 5L grade X65 seamed steel pipes processed by TMCP. Steel B has a chemical composition which classifies it as a low-carbon - high manganese, microalloyed, that meets the specification for API 5L grade for X65 steel standard (classical chemical composition aiming to reach the required mechanical properties) ${ }^{15}$.

\subsection{Dilatometric Tests}

The dilatometric tests were performed in a LINSEIS Quenching Dilatometer L78 RITA. In the first stage of this study, these tests were carried out in order to study the austenite decomposition kinetics. All specimens in this work had the same cylindrical geometry: $3 \mathrm{~mm} \times 10 \mathrm{~mm}$. The temperatures were measured using $\mathrm{K}$ type thermocouples spot-welded in the middle of the specimens.

Specimens of both steels were heated with a constant rate of $5^{\circ} \mathrm{C} / \mathrm{s}$ to $1000^{\circ} \mathrm{C}$. Each one was held at this temperature for $180 \mathrm{~s}$ and, then, cooled to room temperature at different cooling rates: $1^{\circ} \mathrm{C} / \mathrm{s}, 3^{\circ} \mathrm{C} / \mathrm{s}, 5^{\circ} \mathrm{C} / \mathrm{s}, 10^{\circ} \mathrm{C} / \mathrm{s}, 20^{\circ} \mathrm{C} / \mathrm{s}, 30^{\circ} \mathrm{C} / \mathrm{s}$, $50^{\circ} \mathrm{C} / \mathrm{s}, 100^{\circ} \mathrm{C} / \mathrm{s}$ and $200^{\circ} \mathrm{C} / \mathrm{s}$.

The start and final temperatures of austenite decomposition during continuous cooling in non-equilibrium conditions $\left(\mathrm{Ar}_{3}\right.$ and $\mathrm{Ar}_{1}$ ) were determined for each cooling rate. Thus, the experimental CCT diagrams were plotted from the cooling dilatometric curves. The kinetic of austenite decomposition into ferrite and eutectoid aggregates (transformation products such pearlite and bainite) was evaluated.

The Johnson-Mehl-Avrami-Kolmogorov (JMAK) model (Equation 1), adapted to non-isothermal transformations, was used to describe the austenite decomposition kinetic in both studied steels.

$$
f(t)=1-\exp \left(-K t^{n}\right)
$$

Where $f(t)$ is the volume fraction of the transformed phase at a transformation time $t$ and $n$ is the growth exponent, known as Avrami's exponent, which is related to new phases nucleation mechanisms. $K$ is a temperature-dependent kinetic parameter directly related to growth rate and nucleation frequency ${ }^{25,26}$.

\subsection{Microstructural Characterization}

Focusing on the evaluation of the effects of cooling rate on microstructure, the second stage of this research characterized four specimens of each steel subjected to specific cooling rates: $1{ }^{\circ} \mathrm{C} / \mathrm{s}, 10^{\circ} \mathrm{C} / \mathrm{s}, 50^{\circ} \mathrm{C} / \mathrm{s}$ and $100^{\circ} \mathrm{C} / \mathrm{s}$. Thus, the surfaces were metallographically prepared for microstructural analysis and Vickers microhardness testing in order to confirm the transformation products after austenite decomposition. They were cut using diamond disc and their cross sections were polished and chemically etched with 2 vol.\% Nital. The metallographic evaluation was performed using Scanning Electron Microscope (SEM) using a TESCAN Vega 3 equipment.

Table 1. Chemical composition of the studied steels (wt.\%).

\begin{tabular}{cccccccccccc}
\hline Steel & $\mathrm{C}$ & $\mathrm{Mn}$ & $\mathrm{Nb}$ & $\mathrm{Ti}$ & $\mathrm{V}$ & $\mathrm{P}$ & $\mathrm{S}$ & $\mathrm{Cr}$ & $\mathrm{Si}$ & $\mathrm{Ni}$ \\
\hline $\mathbf{A}$ & 0.043 & 0.260 & 0.089 & 0.012 & $* * *$ & 0.009 & 0.001 & 0.490 & 0.190 & 0.150 \\
$\mathbf{B}$ & 0.080 & 1.250 & 0.041 & 0.001 & 0.003 & 0.010 & 0.006 & 0.010 & 0.256 & 0.010 \\
\hline
\end{tabular}


In this research, Vickers microhardness test was performed using a PANTEC HXD 1000TM equipment, consisting of 30 measurements randomly sampled in the central region over the surface of each specimen applying an indentation load of $0,2 \mathrm{kgf}$ during $5 \mathrm{~s}$.

\section{Results and Discussion}

\subsection{Experimental CCT Diagrams}

The first derivative method was used to ascertain the $\mathrm{Ar}_{3}$ and $\mathrm{Ar}_{1}$ temperatures from the dilatometric curves $\left(\Delta \mathrm{L} / \mathrm{L}_{0}(\varepsilon)\right.$ $\mathrm{x}$ Temperature $(\mathrm{T})$ ) of all studied cooling rates. Fig. 1 show, as an example, the dilatometric curve and its first derivative $\left(\frac{d \varepsilon}{d T}\right)$ for steels $\mathrm{A}$ and $\mathrm{B}$ subjected to the cooling rate of $50^{\circ} \mathrm{C} / \mathrm{s}$. $\mathrm{Ar}_{3}$ was estimated nearly where the first derivative begins to deviate from linear course at right side. $\mathrm{The}^{\mathrm{Ar}}{ }_{1}$ was estimated where the first derivative is again linear at left ${ }^{27}$.

Based on this method, it was possible to plot the experimental CCT diagrams for the two steels. Fig. 2 presents a comparison between their experimental diagrams.

Clearly, the higher the cooling rate, the lower the $\mathrm{Ar}_{3}$ and $\mathrm{Ar}_{1}$ for steels $\mathrm{A}$ and $\mathrm{B}$. Higher cooling rates decrease the austenite to ferrite transformation temperature, increasing the level of undercooling of austenite and, thus, the driving force for austenite decomposition. Increased cooling rates promote the reduction in the critical radius for nucleation of new phases, intensifying the nucleation rate of ferrite which leads to ferrite grain refinement. Initially in the austenite decomposition, even if the temperature decreases, the fraction of atoms that have thermal energy high enough to allow them to overcome the activation barrier will be greater than that expected under equilibrium conditions, favoring the diffusional processes and, hence, accelerating the progress of transformation ${ }^{28,29}$.

However, further increasing the cooling rate and, then, lowering the austenite to ferrite transformation temperature, the energy available for diffusion and growth of new phases decreases, slowing the transformation kinetic ${ }^{14,28-31}$.

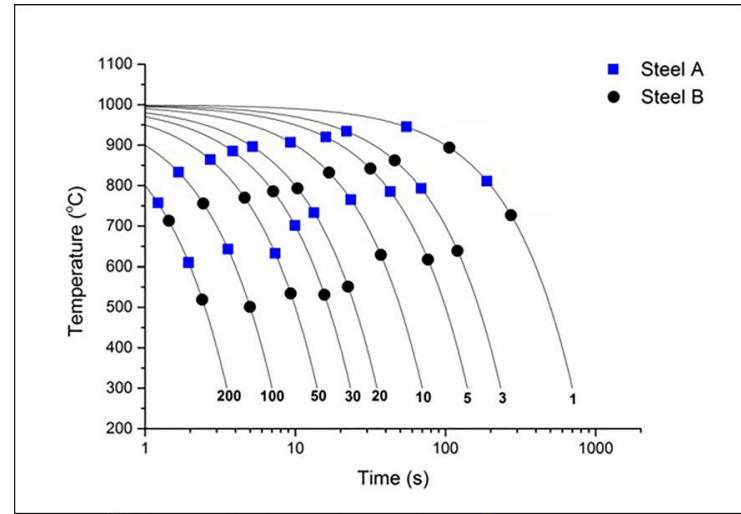

Figure 2. Comparison between the experimental CCT diagrams for steels A and B.

Thus, it is expected that the higher the cooling rate, the more refined the microstructure.

It is noted that the CCT diagram of steel $\mathrm{B}$ is downwards shifted in comparison to steel A. Austenite stability is enhanced by $\mathrm{Nb}$ and $\mathrm{Mn}$ in solid solution. $\mathrm{Nb}$, in solid solution, segregates to austenite grain boundaries where it interacts with carbon, reducing the local driving force for ferrite nucleation and prevents the diffusion of carbon from ferrite. Thus, the austenite decomposition is delayed ${ }^{28-31}$. Steel $\mathrm{A}$ has higher $\mathrm{Nb}$ and lower $\mathrm{C}$ and $\mathrm{Mn}$ contents. However, its $\mathrm{Ar}_{3}$ and $\mathrm{Ar}_{1}$ temperatures were higher than those achieved in steel $\mathrm{B}$ which, in comparison, presents higher $\mathrm{C}$ and $\mathrm{Mn}$ contents. Thus, it was expected lower transformations temperatures for steel $\mathrm{A}$. The austenitizing temperature of $1000^{\circ} \mathrm{C}$ was not sufficiently to dissolve $\mathrm{Nb}$ compounds $(\mathrm{Nb})(\mathrm{C}, \mathrm{N})$. Thus, the results corroborate the hypothesis that large portion of $\mathrm{Nb}$ content is present as niobium carbide and/or carbonitride compounds in steels during the transformation and does not significantly influence the austenite decomposition kinetic, being the $\mathrm{C}$ and $\mathrm{Mn}$ contents the main chemical difference between the studied steels that justifies the verified behavior ${ }^{4,32}$.
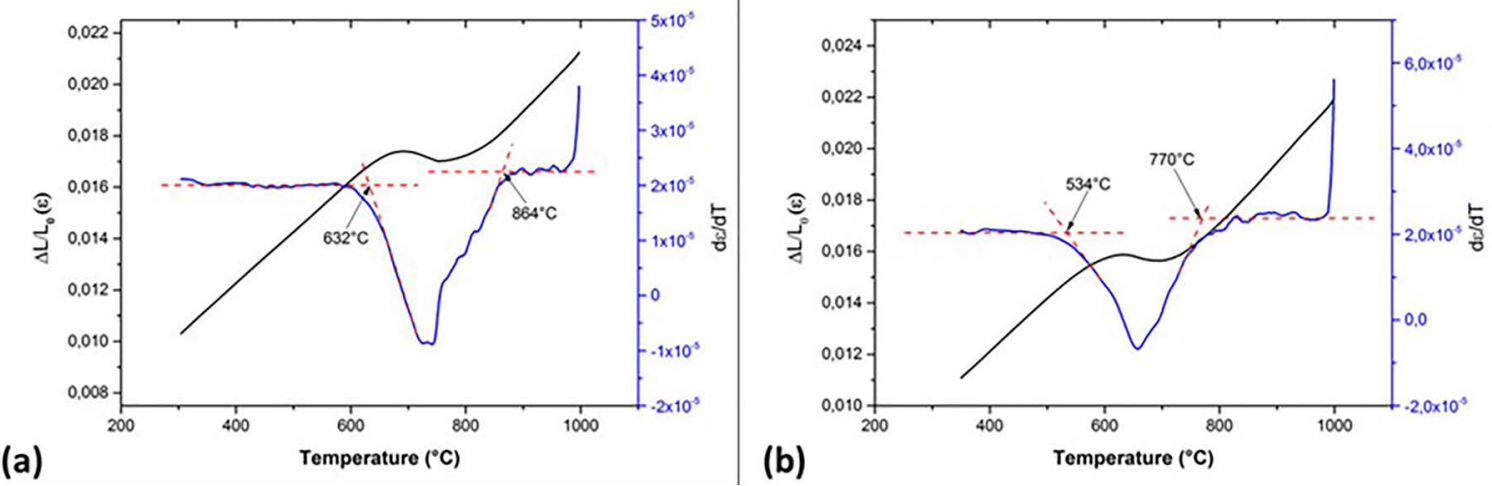

Figure 1. Example of application of the first derivative method to ascertain $\mathrm{Ar}_{3}$ and $\mathrm{Ar}_{1}$ temperatures from studied steels: (a) steel A, (b) steel B. 


\subsection{Phase Transformation Kinetics}

The fraction of transformed products during continuous cooling was estimated using the lever rule between Ar3 and $\operatorname{Ar} 1{ }^{24,33}$.

From the experimental dilatometry data after submitting the steels to the cooling rates of $1^{\circ} \mathrm{C} / \mathrm{s}, 3^{\circ} \mathrm{C} / \mathrm{s}, 5^{\circ} \mathrm{C} / \mathrm{s}, 10^{\circ} \mathrm{C} / \mathrm{s}$, $20^{\circ} \mathrm{C} / \mathrm{s}, 30^{\circ} \mathrm{C} / \mathrm{s}, 50^{\circ} \mathrm{C} / \mathrm{s}, 100^{\circ} \mathrm{C} / \mathrm{s}$ and $200^{\circ} \mathrm{C} / \mathrm{s}$, the JMAK model was fitted to the experimental data in order to describe the austenite decomposition kinetic. As an example of this procedure, Fig. 3 presents the volume fraction of transformed products achieved using the lever rule in the dilatometric curve of steel $\mathrm{A}$ and $\mathrm{B}$ cooled at $100^{\circ} \mathrm{C} / \mathrm{s}$ and these experimental data fitted to the JMAK equation.

Table 2 presents the Avrami's equation parameters $k$ and $n$, as well the statistical parameter $R^{2}$, obtained from the JMAK fitting to the experimental data.

The values of the parameter $k$ become larger as the cooling rate increases, indicating an increase in average transformation rate. The values of parameter $n$ were approximately between 4 and 7 . At $200^{\circ} \mathrm{C} / \mathrm{s}$, excessively high values of $n$ were found. The observed dispersion which may indicate alterations in the nucleation physics of some constituent of steels.

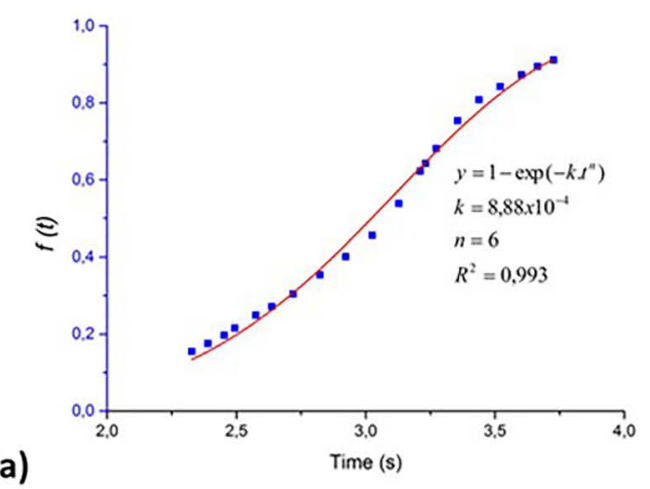

Fig. 4 presents the experimental results compared with JMAK model used in predicting the transformation behavior for both steels. The experimental data were fitted to the JMAK model and it is possible to observe that the model reproduces accurately the experimental data and can therefore be used efficiently to describe and predict the phase transformations in these steels.

Fig. 5 shows the instantaneous transformation rate $\left(\frac{d f(t)}{d t}\right)$ for both steels. For all the investigated cooling rates, these curves presented a peak function behavior. At the beginning of the transformation, the rate continuously increases to a maximum value and then, decreases until the complete austenite decomposition. This behavior, as already mentioned, can be explained by the variation of the amount of atoms that have sufficient energy to overcome the energy barriers of the short-and-long range diffusion process ${ }^{14,28-31}$.

For better visualization, the numbers above each peak in the Fig. 5 represent the respective time intervals to reach the maximum transformation rates. It is possible to observe that, in general, the time to reach the highest transformation rate is shorter for steel $\mathrm{A}$. This is in accordance with its chemical composition. Among the elements present in austenitic solid solution at the studied austenitizing temperature $\left(1000^{\circ} \mathrm{C}\right)$, the $\mathrm{Mn}$ effect must be highlighted.

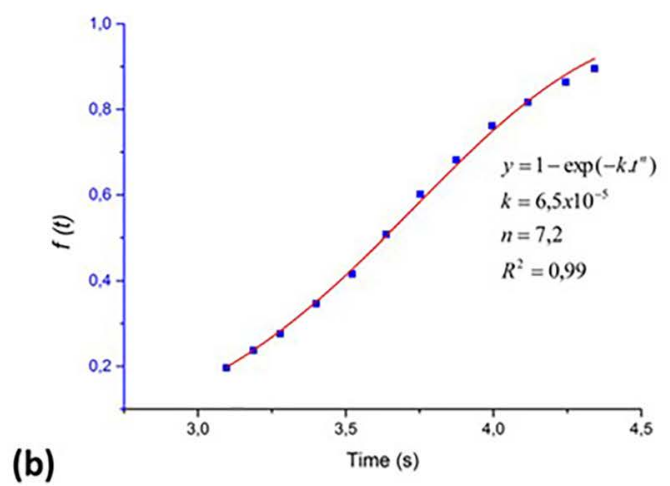

Figure 3. Experimental dilatometry data fitted to the JMAK model: (a) steel A, (b) steel B.

Table 2. Avrami's equation parameters and statistical parameter $\mathrm{R}^{2}$.

\begin{tabular}{ccccccc}
\hline & \multicolumn{3}{c}{ Steel A } & \multicolumn{3}{c}{ Steel B } \\
\hline Cooling rates $\left({ }^{\circ} \mathbf{C} / \mathbf{s}\right)$ & $\mathbf{K}$ & $\mathbf{n}$ & $\mathbf{R}^{2}$ & $\mathbf{k}$ & $\mathbf{n}$ & $\mathbf{R}^{2}$ \\
\hline $\mathbf{1}$ & $1,06 \mathrm{E}-08$ & 3,7 & 0,982 & $1,64 \mathrm{E}-10$ & 4,1 & 0,987 \\
$\mathbf{3}$ & $1,19 \mathrm{E}-08$ & 4,5 & 0,985 & $1,88 \mathrm{E}-10$ & 5,0 & 0,994 \\
$\mathbf{5}$ & $1,25 \mathrm{E}-08$ & 5,1 & 0,985 & $6,96 \mathrm{E}-11$ & 5,8 & 0,999 \\
$\mathbf{1 0}$ & $1,21 \mathrm{E}-07$ & 5,4 & 0,991 & $1,33 \mathrm{E}-09$ & 5,9 & 0,995 \\
$\mathbf{2 0}$ & $9,88 \mathrm{E}-06$ & 4,7 & 0,997 & $2,73 \mathrm{E}-08$ & 6,2 & 0,997 \\
$\mathbf{3 0}$ & $4,83 \mathrm{E}-05$ & 4,6 & 0,997 & $7,02 \mathrm{E}-08$ & 6,8 & 0,993 \\
$\mathbf{5 0}$ & $8,75 \mathrm{E}-05$ & 5,4 & 0,999 & $3,52 \mathrm{E}-06$ & 6,4 & 0,997 \\
$\mathbf{1 0 0}$ & $8,88 \mathrm{E}-04$ & 6,0 & 0,993 & $6,51 \mathrm{E}-05$ & 7,2 & 0,997 \\
$\mathbf{2 0 0}$ & $3,61 \mathrm{E}-05$ & 16,3 & 0,982 & $5,99 \mathrm{E}-04$ & 10,3 & 0,991 \\
\hline
\end{tabular}


(a)

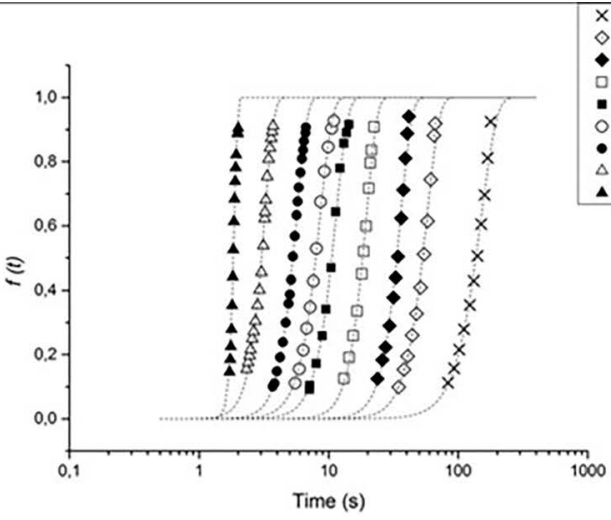

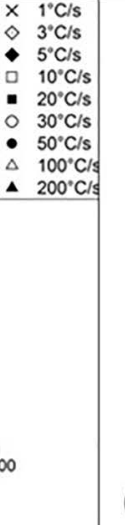

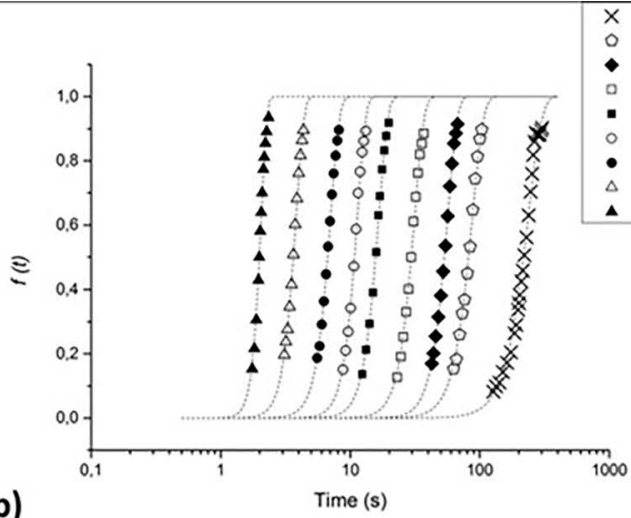

Figure 4. Experimental data fitted to the results from JMAK model: (a) steel A, (b) steel B.
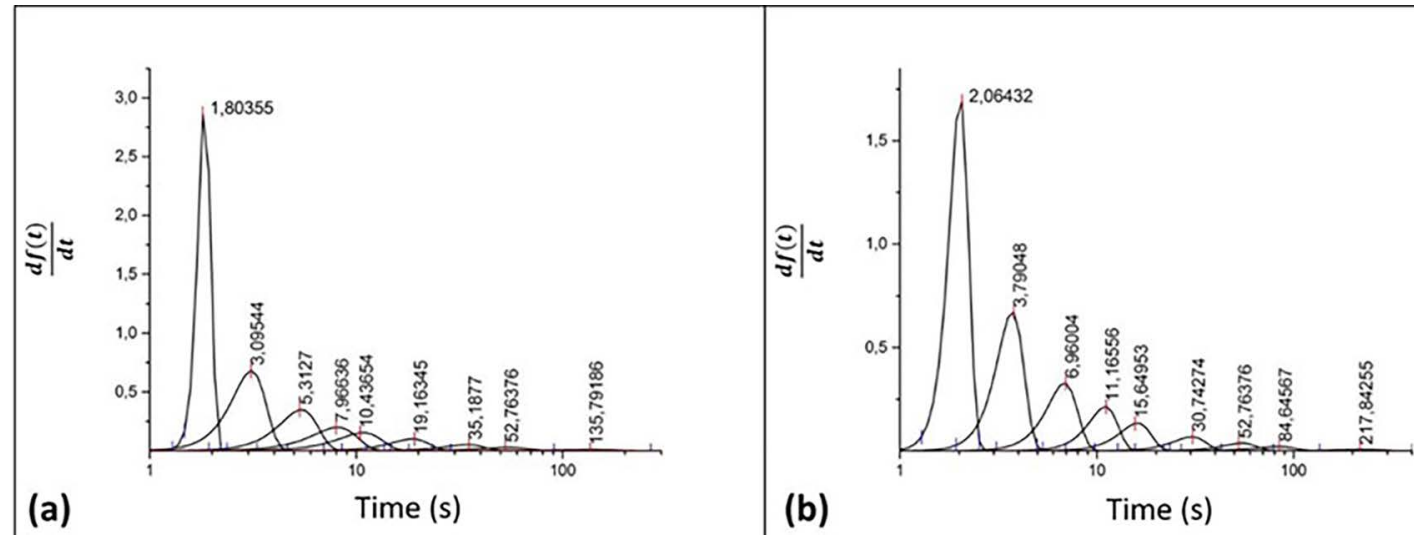

Figure 5. Instantaneous transformation rates as a function of time: (a) steel A, (b) steel B.

This element strongly contributes to the increase of activation energy for the $\gamma \rightarrow \alpha$ transformation. Due to that, as the $\mathrm{Mn}$ content of steel A is the lowest, the transformation will be favored for lower undercooling degrees, justifying the shortest transformation time when compared to steel B which has higher Mn content ${ }^{34,35}$.

In order to verify the representativeness of the JMAK model to predict these continuous cooling transformations, CCT diagrams were simulated. For each studied steel, applying the fitting constants presented in Table 2 to the JMAK equation (Equation 1) and considering the beginning of the transformation at the instant when $1 \%$ of austenite has been transformed $(\mathrm{f}=0.01)$ and the end when $99 \%$ of the austenite has been decomposed $(\mathrm{f}=0.99)$, the time $(\mathrm{t})$ corresponding to the transformation beginning and the end were calculated for all evaluated cooling rates.

For each cooling condition, as the cooling rate was constant, from the austenitizing temperature $\left(1000^{\circ} \mathrm{C}\right)$ until the room temperature, it was possible to calculate all critical temperatures $\left(\mathrm{Ar}_{3}\right.$ and $\left.\mathrm{Ar}_{1}\right)$ applying the Equations 2 and 3 .

$$
\begin{aligned}
& A r_{3}=1000-[\text { cooling rate }] \times[t(f=0.01)] \\
& A r_{1}=1000-[\text { cooling rate }] \times[t(f=0.99)]
\end{aligned}
$$

Fig. 6 shows the comparison between the experimental and calculated diagrams, in which the numbers below each curve represent the cooling rates $\left({ }^{\circ} \mathrm{C} / \mathrm{s}\right)$. Based on experimental data about the fraction of transformed phases and the parameters of JMAK equation, it can be stated that the applied model is in good agreement with the experimental data and was efficient to characterize the transformation kinetics for both steels ${ }^{36}$.

\subsection{Microstructural and Microhardness Characterization}

Fig. 7 presents a comparison of the Vickers microhardness between steels $\mathrm{A}$ and $\mathrm{B}$ subjected to the cooling rates of $1{ }^{\circ} \mathrm{C} / \mathrm{s}, 10^{\circ} \mathrm{C} / \mathrm{s}, 50{ }^{\circ} \mathrm{C} / \mathrm{s}$ and $100{ }^{\circ} \mathrm{C} / \mathrm{s}$.

It can be seen from Fig. 7 that the measured microhardness values increase as the cooling rate is increased. By comparison, higher microhardness values are achieved in steel $\mathrm{B}$ which has higher $\mathrm{Mn}$ and lower $\mathrm{Nb}$ content than steel A. Beidokhti et al. ${ }^{37}$ found that the refining and hardening effects of manganese exert two opposing influences on the weld properties. The microstructural refining improves the impact properties of the weld, but the hardening effect of manganese reduces the weld metal toughness. 
The microstructural evolution with the cooling rate was obtained using SEM and detailed observations are shown in Fig. 8 to 11. The results have confirmed that the microstructure of steel $\mathrm{A}$ and $\mathrm{B}$, cooled at $1{ }^{\circ} \mathrm{C} / \mathrm{s}$ (Fig. 8) is consisted of ferrite and pearlite in which the largest pearlite fraction is found in steel $\mathrm{B}$ which had higher C content. For $10^{\circ} \mathrm{C} / \mathrm{s}$ cooling rate (Fig. 9), both steels presented microstructures constituted of polygonal ferrite, quasi-polygonal ferrite and bainitic ferrite. Samples of both steels subjected to the cooling rate of 50 and $100^{\circ} \mathrm{C} / \mathrm{s}$ (Fig. 10 and 11) is composed by quasi-polygonal ferrite and bainitic ferrite.

It is clear the effect of the increasing cooling rate on the ferrite grain refinement for steels A and B. Higher cooling rates intensified the ferrite nucleation rate which restricted the grain growth leading to a fine-grained microstructure with low transformation temperatures products.
Increasing the cooling rate, the morphology of ferrite has been altered from polygonal to lath and acicular type ferrite ${ }^{38}$.

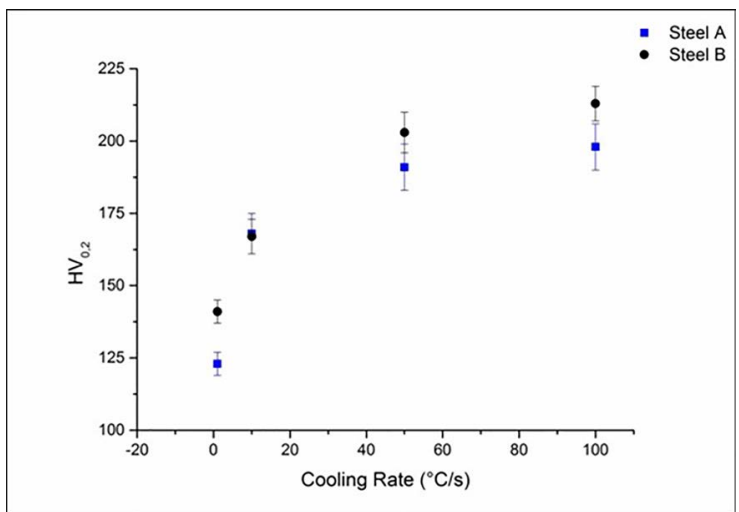

Figure 7. Vickers microhardness of steels A and B after cooling at described cooling rates. (a)

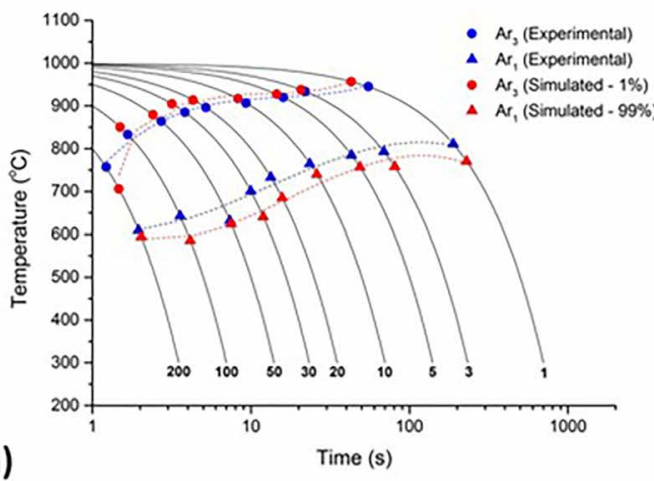

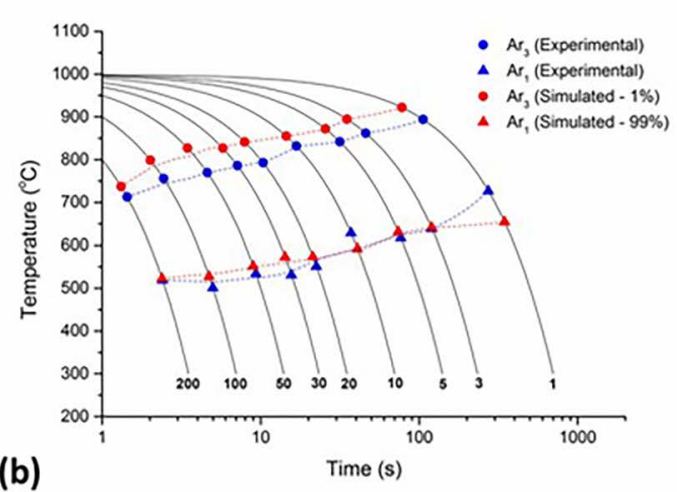

Figure 6. Comparison between experimental and calculated CCT diagrams: (a) steel A, (b) steel B.

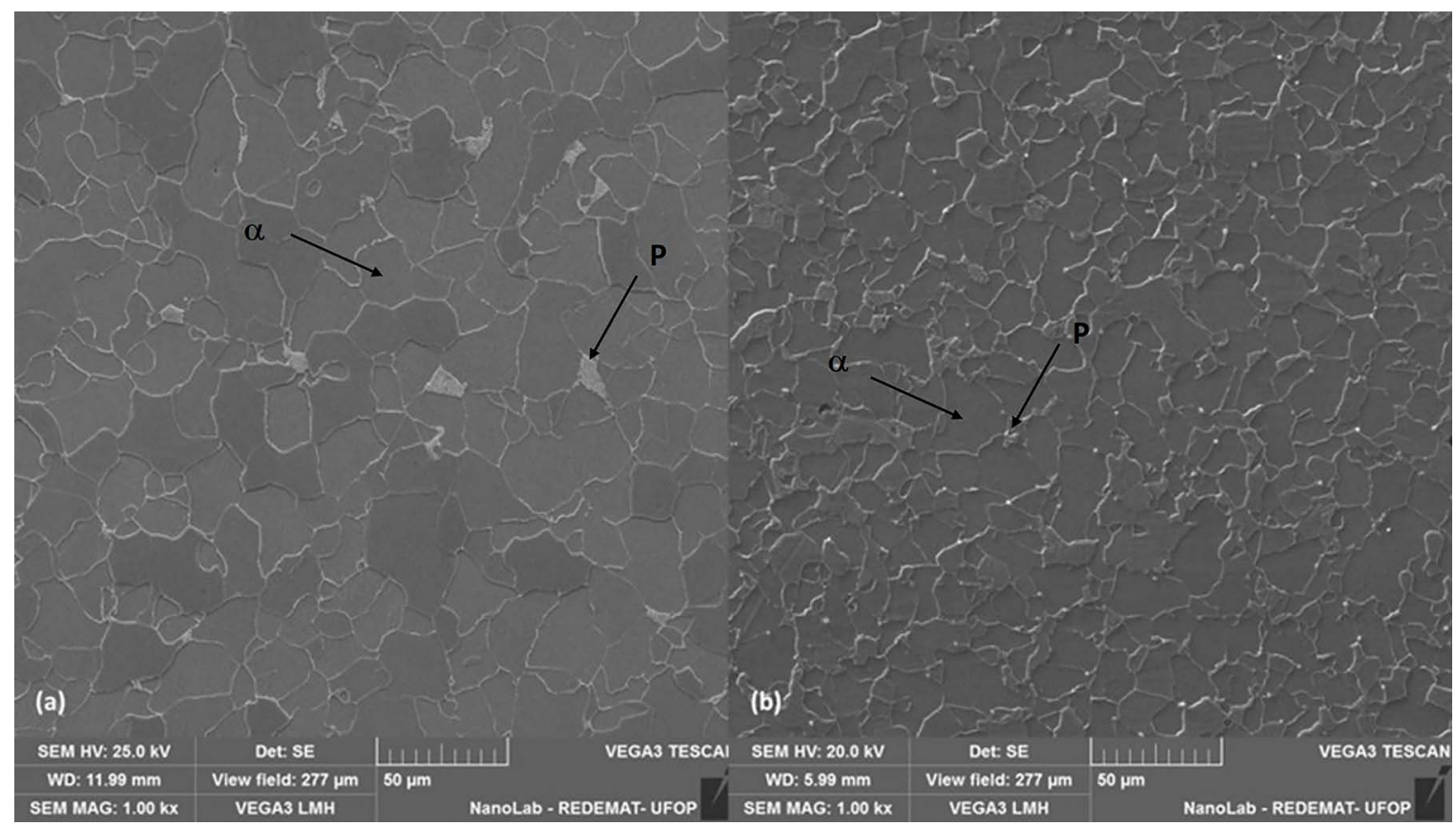

Figure 8. SEM micrographs of microstructures of (a) steel A and (b) steel B cooled with $1^{\circ} \mathrm{C} / \mathrm{s}-1000 \mathrm{X}$ ( $\alpha$-ferrite, $\mathrm{P}$ - pearlite). 


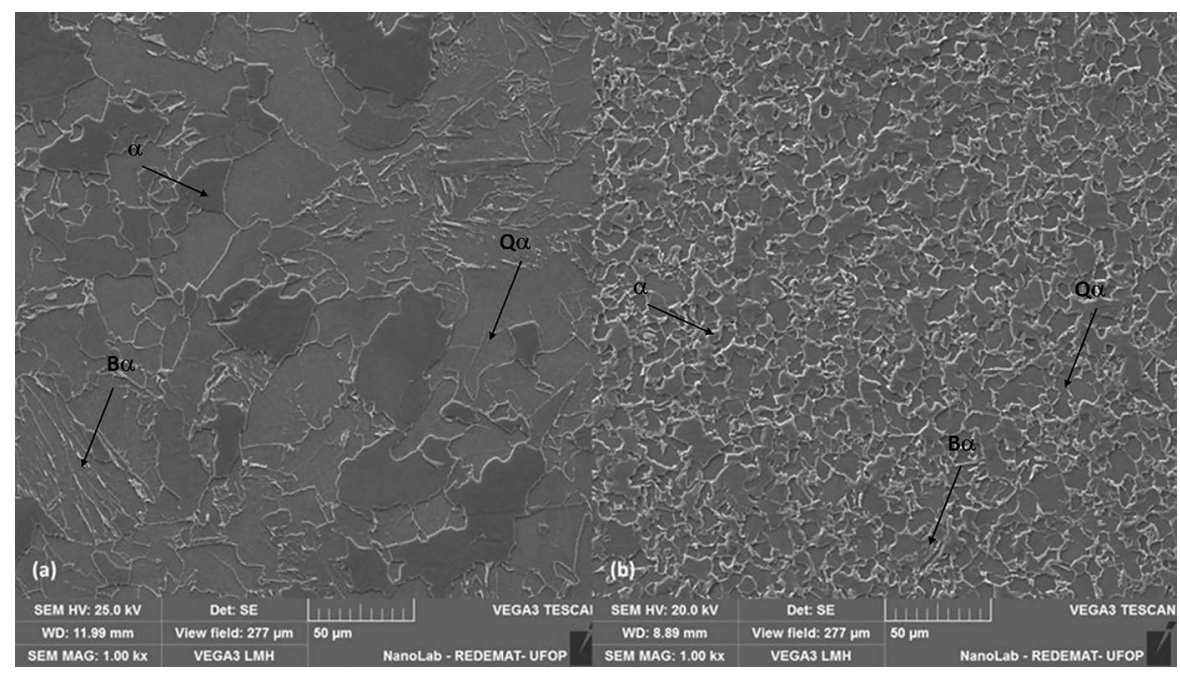

Figure 9. SEM micrographs of microstructures of (a) steel A and (b) steel B cooled with $10^{\circ} \mathrm{C} / \mathrm{s}-1000 \mathrm{X}$ ( $\alpha$-polygonal ferrite, $\mathrm{Q} \alpha$ - quasi-polygonal ferrite and $\mathrm{B} \alpha$ - bainitic ferrite).

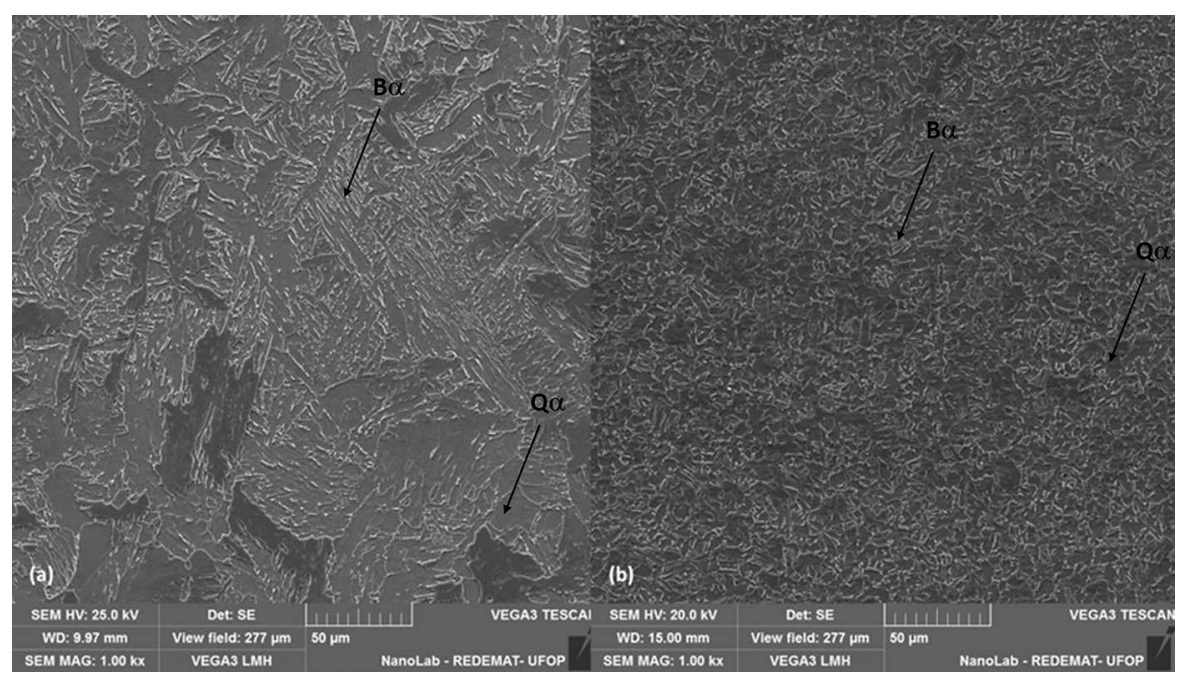

Figure 10. SEM micrographs of microstructures of (a) steel A and (b) steel B cooled with $50^{\circ} \mathrm{C} / \mathrm{s}-1000 \mathrm{X}$ ( $\mathrm{Q} \alpha$ - quasi-polygonal ferrite and $\mathrm{B} \alpha$ - bainitic ferrite).

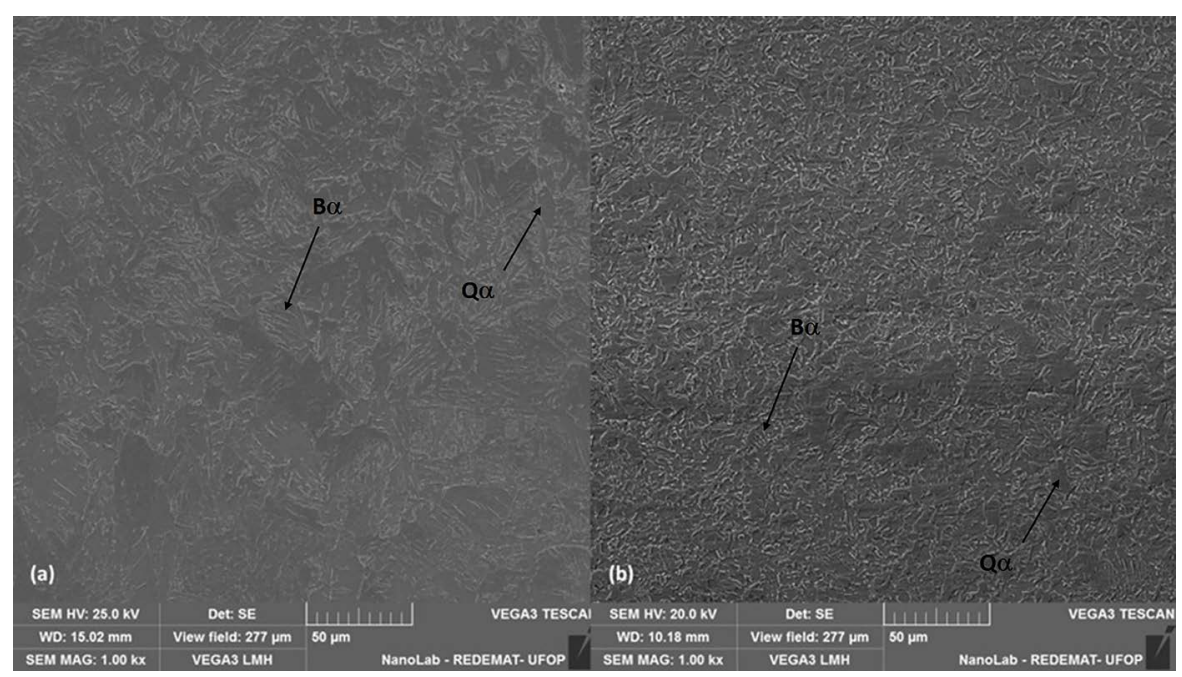

Figure 11. SEM micrographs of microstructures of (a) steel A and (b) steel B cooled with $100^{\circ} \mathrm{C} / \mathrm{s}-1000 \mathrm{X}$ ( $Q \alpha$ - quasi-polygonal ferrite and $\mathrm{B} \alpha$ - bainitic ferrite). 


\section{Conclusions}

Despite the higher $\mathrm{Nb}$ content in steel $\mathrm{A}$, its $\mathrm{Ar}_{3}$ and $\mathrm{Ar}_{1}$ temperatures were higher than the achieved in steel $\mathrm{B}$, which has higher Mn content. The evaluated austenitizing temperature $\left(1000^{\circ} \mathrm{C}\right)$ was not sufficiently high to dissolve $\mathrm{Nb}$ compounds. Thus, in the critical evaluated condition, the $\mathrm{Nb}$ content did not significantly influence the austenite decomposition kinetic and the Mn content dictated the transformation in the two steels, being an important element to achieve the refinement of transformed products in conditions where the initial austenite grains are not deformed and $\mathrm{Nb}$ are not completely in solid solution.

For the studied austenitizing condition, higher microhardness values are achieved in steel B which has higher Mn and lower $\mathrm{Nb}$ content than steel A. The lower Mn content in steel A promoted loss of grain refinement, decreasing the steel hardness.

The JMAK model was fitted to the experimental data and it is possible to observe that the model reproduces satisfactorily the experimental data. The JMAK constants, determined in this study and available in this paper, can then be used efficiently to describe and to predict the phase transformations in the studied steels considering non-deformed austenite grains and low $\mathrm{Nb}$ content in solid solution.

\section{Acknowledgements}

The authors thank the Conselho Nacional de Desenvolvimento Científico e Tecnológico (CNPq) for the financial support.

\section{References}

1. Gong P, Palmiere E, Rainforth W. Thermomechanical processing route to achieve ultrafine grains in low carbon microalloyed steels. Acta Materialia. 2016;119:43-54.

2. Zhao MC, Yang K, Shan Y. The effects of thermo-mechanical control process on microstructures and mechanical properties of a commercial pipeline steel. Materials Science and Engineering: A. 2002;335(1-2):14-20.

3. Calvo J, Jung IH, Elwazri AM, Bai DQ, Yue S. Influence of the chemical composition on transformation behaviour of low carbon microalloyed steels. Materials Science and Engineering: A. 2009;520(1-2):90-96.

4. Gong P, Palmiere EJ, Rainforth W. Dissolution and precipitation behaviour in steels microalloyed with niobium during thermomechanical processing. Acta Materialia. 2015;97:392-403.

5. Hashemi SH, Mohammadyani D. Characterisation of weldment hardness, impact energy and microstructure in API X65 steel. International Journal of Pressure Vessels and Piping. 2012;98:8-15.

6. Shi Y, Han Z. Effect of weld thermal cycle on microstructure and fracture toughness of simulated heat-affected zone for a $800 \mathrm{MPa}$ grade high strength low alloy steel. Journal of Materials Processing Technology. 2008;207(1-3):30-39.
7. Rai G, Mukherjee SK. Cracking of weldments in pipes manufactured by ERW process: An analysis. Engineering Fracture Mechanics. 1982;16(4):527-537.

8. Castelluccio GM, Perez-Ipiña JE, Yawny A, Ernst HA. Fracture testing of the heat affected zone from welded steel pipes using an in situ stage. Engineering Fracture Mechanics. 2013;98(1):52-63.

9. Chung PC, Ham Y, Kim S, Lim J, Lee C. Effects of postweld heat treatment cycles on microstructure and mechanical properties of electric resistance welded pipe welds. Materials and Design. 2012;34:685-690.

10. Paddea S, Francis JA, Paradowska AM, Bouchard PJ, Shibli IA. Residual stress distributions in a P91 steel-pipe girth weld before and after post weld heat treatment. Materials Science and Engineering: A. 2012;534:663-672.

11. Yan P, Güngör ÖE, Thibaux P, Liebeherr M, Bhadeshia HKDH. Tackling the toughness of steel pipes produced by high frequency induction welding and heat-treatment. Materials Science and Engineering: A. 2011;528(29-30):8492-8499.

12. Shu-Biao Y, Xin-Jun S, Qing-You L, Zhi-Bo Z. Influence of deformation of low-carbon and high Nb-containing steel during continuous cooling. Journal of Iron and Steel Research International. 2010;17(2):43-47.

13. Zhao MC, Yang K, Xiao F, Shan Y. Continuous cooling transformation of undeformed and deformed low carbon pipeline steels. Materials Science and Engineering: A. 2003;355(1-2):126-136.

14. Mecozzi MG, Sietsma J, Van der Zwaag S. Analysis of $\gamma \rightarrow \alpha$ transformation in a $\mathrm{Nb}$ micro-alloyed $\mathrm{C}-\mathrm{Mn}$ steel by phase field modelling. Acta Materialia. 2006;54(5):1431-1440.

15. Hashemi SH. Strength-hardness statistical correlation in API X65 steel. Materials Science and Engineering: A. 2011;528(3):16481655 .

16. Long L, Hua D, Lin-Xiu D, Jing-Lin W, Hong-Mei S, Pi-Jun $\mathrm{Z}$. Influence of $\mathrm{Mn}$ content and hot deformation transformation behavior of C-Mn steels. Journal of Iron and Steel Research International. 2008;15(2):51-55.

17. Van Tol RT, Zhao L, Sietsma J. Kinetics of austenite decomposition in manganese-based steel. Acta Materialia. 2014;64:33-40.

18. Hejazi D, Haq AJ, Yazdipour N, Dunne DP, Calka A, Barbaro F, Pereloma EV. Effect of manganese content and microstructure on the susceptibility of X70 pipeline steel to hydrogen cracking. Materials Science and Engineering: A. 2012;551:40-49.

19. Nayak SS, Misra RDK, Hartmann J, Siciliano F, Gray JJ. Microstructure and properties of low manganese and niobium containing HIC pipeline steel. Materials Science and Engineering: A. $2008 ; 494(1-2): 456-463$.

20. Takahashi A, Iino M. Thermo-mechanical control process as a tool to grain-refine the low manganese containing steel for sour service line pipe. ISIJ International. 1996;36(2):235-240.

21. Chen G, Yang W, Guo S, Sun Z. Effect of Nb on the transformation kinetics of low carbon (manganese) steel during deformation of undercooled austenite. Journal of University of Science and Technology Beijing, Mineral, Metallurgy, Material. 2006;13(5):411-415. 
22. Yan C, Dantian Z, Yongchang L, Huijun L, Dakun X. Effect of dissolution and precipitation of $\mathrm{Nb}$ on the formation of acicular ferrite/bainite ferrite in low-carbon HSLA steels. Materials Characterization. 2013;84:232-239.

23. Yu Q, Sun Y. Abnormal growth of austenite grain of low-carbon steel. Materials Science and Engineering: A. 2006;420(1-2):34-38.

24. Park JS, Lee $\mathrm{YK} . \mathrm{Nb}(\mathrm{C}, \mathrm{N})$ precipitation kinetics in the bainite region of a low-carbon $\mathrm{Nb}$-microalloyed steel. Scripta Materialia. 2007;57(2):109-112.

25. Lei X, Huang J, Jin X, Chen S, Zhao X. Application of JohnsonMehl-Avrami-Kolmogorov type equation in non-isothermal phase process: Re-discussion. Materials Letters. 2016;181:240-243.

26. Martin D. Application of Kolmogorov-Johnson-Mehl-Avrami equations to non-isothermal conditions. Computational Materials Science. 2010;47(3):796-800.

27. Park BJ, Choi JM, Lee KJ. Analysis of phase transformations during continuous cooling by the first derivative of dilatation in low carbon steels. Materials Characterization. 2012;64:8-14.

28. Goune M, Danoix D, Agren J, Bréchet Y, Hutchinson CR, Militzer M, Purdy GR, Van der Zwaag S, Zurob H. Overview of the current issues in austenite to ferrite transformation and the role of migrating interfaces therein for low alloyed steels. Materials Science and Engineering: R: Reports. 2015;92:1-38.

29. Militzer M, Pandi R, Hawbolt EB. Ferrite nucleation and growth during continuous cooling. Metallurgical and Materials Transactions A. 1996;27(6):1547-1556

30. Manohar PA, Chandra T, Killmore CR. Continuous cooling transformation behavior of microalloyed steels containing $\mathrm{Ti}$, $\mathrm{Nb}, \mathrm{Mn}$ and Mo. ISIJ International. 1996;36(12):1486-1493.
31. Zhao S, Wei D, Li R, Zhang L. Effect of cooling rate on phase transformation and microstructure of Nb-Ti microalloyed steel. Materials Transactions. 2014;55(8):1274-1279.

32. Cao JC, Liu QY, Yong Q, Sun XJ. Effect of Niobium on Isothermal Transformation of Austenite to Ferrite in HSLA LowCarbon Steel. Journal of Iron and Steel Research, International. 2007;14(3):52-56.

33. Gómez MN, Medina SF, Caruana G. Modelling of phase transformation kinetics by correction of dilatometry results for a ferritic Nb-microalloyed steel. ISIJ International. 2003;43(8):1228-1237.

34. Ravi AM, Sietsma J, Santofimia MJ. Exploring bainite formation kinetics distinguishing grain-boundary and autocatalytic nucleation in high and low-Si steels. Acta Materialia. 2016;(105):155-164.

35. Vasilyev AA, Sokolov SF, Kolbasnikov NG, Sokolov DF. Effect of alloying on the self-diffusion activation energy in $\gamma$-iron. Physics of the Solid State. 2011;53(11):2194-2200.

36. Singh SB, Krishnan K, Sahay SS. Modeling non-isothermal austenite to ferrite transformation in low carbon steels. Materials Science and Engineering: A. 2007;445-446:310-315.

37. Beidokhti B, Koukabi AH, Dolati A. Influences of titanium and manganese on high strength low alloy SAW weld metal properties. Materials Characterization. 2009;60(3):225-233.

38. Shanmugam S, Ramisetti NK, Misra RDK, Mannering T, Panda D, Jansto S. Effect of cooling rate on the microstructure and mechanical properties of Nb-microalloyed steels. Materials Science and Engineering: A. 2007;460-461:335-343. 